\title{
Validasi Modul "Cakap" untuk Meningkatkan Keterampilan Sosial Mahasiswa Baru Asal Bali
}

\author{
Ni Made Yanthi Ary Agustini' ${ }^{1}$ E Budi Andayani \\ Fakultas Psikologi Universitas Gadjah Mada
}

\begin{abstract}
Having low social skills can make individuals experience difficulty adjusting to a new environment. The purpose of this research is to validate "CAKAP" module to improve social skills. This study used a quantitative approach with the quasiexperimental design of The Untreated Control Group Design with Pretest and Posttest. Social skills scale, observation sheet, and evaluation sheet were adiministrated to 14 freshmen from Bali who joined in Keluarga Mahasiswa Hindu Dharma (KMHD). The test results of the content validity of the module using Aiken's $\mathrm{V}$ shows a value ranging from 0,734-0,861 for each session which means the module has good content validity. Empirical test results showed that there was a difference gained score between experimental group and control group $(\mathrm{z}=-2,194, \mathrm{p}=0,026, \mathrm{p}<0,05)$. The results show that the module "CAKAP" is valid to improve social skills on freshmen from Bali.
\end{abstract}

Keywords: bali; freshmen; "CAKAP" module validation; social skills

\begin{abstract}
Abstrak. Keterampilan sosial yang rendah menyebabkan individu mengalami kesulitan menyesuaikan diri terutama di lingkungan sosial baru. Tujuan dari penelitian ini adalah melakukan validasi modul "CAKAP" untuk meningkatkan keterampilan sosial. Penelitian ini menggunakan pendekatan kuantitatif dengan rancangan eksperimen kuasi The Untreated Control Group Design With Pretest and Posttest. Subjek penelitian adalah 14 orang mahasiswa baru asal Bali yang tergabung dalam Keluarga Mahasiswa Hindu Dharma (KMHD). Instrumen penelitian yang digunakan pada penelitian ini adalah skala keterampilan sosial, lembar observasi, serta lembar evaluasi. Hasil uji validitas isi modul menggunakan Aiken's $V$ menunjukkan nilai yang berkisar 0,734-0,861 untuk setiap sesinya yang berarti modul memiliki validitas isi yang baik. Hasil uji empirik menunjukkan terdapat perbedaan gained score antara kelompok eksperimen dan kelompok kontrol ( $\mathrm{z}=-$ 2,194, $\mathrm{p}=0,026, \mathrm{p}<0,05)$. Hasil penelitian menunjukkan bahwa modul "CAKAP" valid untuk meningkatkan keterampilan sosial pada mahasiswa baru asal Bali.
\end{abstract}

Kata kunci: bali; keterampilan sosial; mahasiswa baru; validasi modul "CAKAP"

Individu yang memasuki masa remaja akan dihadapkan pada situasi memilih pendidikan lanjutan setelah menyelesaikan Sekolah Menengah Atas. Masuk ke

\footnotetext{
1 Korespondensi mengenai isi artikel ini dapat dilakukan melalui : yanthi.ari@mail.ugm.ac.id

2 Atau melalui anikoentjoro@ugm.ac.id
}

perguruan tinggi, remaja dihadapkan pada fase transisi dari struktur sekolah yang lebih besar, interaksi dengan teman sebaya yang lebih beragam latar belakang etnis dan geografisnya, serta bertambahnya tekanan untuk mencapai prestasi (Santrock, 2003). Kehidupan seorang remaja akan berubah ketika mereka 
meninggalkan Sekolah Menengah Atas menuju perguruan tinggi (Abeele \& Roe, 2011).

Permasalahan yang biasanya terjadi berkaitan dengan penyesuaian sosial dan juga akademik pada kehidupan di perguruan tinggi. Berdasarkan penelitian yang dilakukan oleh Paul dan Brier (dalam Abeele \& Roe 2011) ditemukan mahasiswa Amerika yang berada dalam tahun pertama perkuliahan sering mengalami "friendsickness" yaitu kurangnya rasa memiliki antar individu. Mahasiswa tahun pertama akan dihadapkan pada kemampuan untuk menyelesaikan tugas, menghadapi stres terkait perkuliahan, serta menyesuaikan diri secara sosial untuk menghilangkan rasa kesepian dan merasa sendiri (Hall, McNallie, Custers, Timmermans, Wilson, \& Bulk, 2016; Liu \& Chang, 2014).

Mooney dan Gordon (dalam Siregar, 2012) membagi masalah yang terjadi pada mahasiswa ke dalam 12 klasifikasi masalah, yakni: masalah kesehatan dan perkembangan fisik, masalah keuangan serta pekerjaaan yang dihadapi, masalah dalam pengaturan waktu, masalah psikologis individu saat berada di lingkungan sosial, masalah yang berkaitan dengan diri sendiri, masalah dengan hubungan romantis, masalah yang berkaitan dengan orang tua dan keluarga, masalah yang berkaitan dengan agama, masalah dalam menghadapi dunia perkuliahan, masalah dalam karir, masalah yang berkaitan dengan proses belajar di kampus, serta masalah yang menjadi isi terkini (seperti game online, narkoba, atau media sosial).

Berdasarkan data yang diperoleh dari Direktorat Administratif dan Akademik (DAA) UGM pada tahun 2016, total jumlah mahasiswa yang berasal dari Bali lima tahun terakhir terhitung dari tahun 2011 hingga 2015 adalah 426 orang.
Rata-rata lama studi mahasiswa yang berasal dari Bali untuk jenjang $\mathrm{S} 1$ adalah 51,62 bulan atau sekitar 4 tahun 3 bulan, sedangkan untuk jenjang vokasi rata-rata lama studi yaitu 35,67 bulan atau sekitar 2 tahun 9 bulan.

Berdasarkan hasil survei yang dilakukan oleh peneliti di Universitas Gadjah Mada (UGM) bulan Mei 2016 pada mahasiswa asal Bali angkatan tahun 2015 yang tergabung dalam Keluarga Mahasiswa Hindu Dharma (KMHD) UGM diketahui bahwa 14 orang dari 43 orang yang mengisi survei merasakan kurang dapat bersosialisasi dengan lingkungan sekitar. Selain itu terdapat kesulitan untuk berbaur dengan teman-teman baik di kampus maupun di tempat tinggal. Adanya kecenderungan untuk malu memulai pembicaraan membuat mereka lebih sering menyendiri sehingga merasa rindu akan rumah dan juga kesepian. Hasil temuan ini diperkuat dengan wawancara yang dilakukan terhadap empat orang mahasiswa, yaitu PS, CI, AD, dan DW. Hasil wawancara menggambarkan bahwa mahasiswa baru yang berasal dari Bali mengalami kesulitan berinteraksi dengan orang lain, membuka diri dengan orang baru, serta pada saat meminta bantuan dengan orang lain. Hal ini disebabkan oleh adanya perbedaan antara lingkungan yang baru dengan lingkungan tempat individu dibesarkan sehingga individu merasa kurang nyaman di tempat rantauan.

Mahasiswa tahun pertama yang memiliki kesulitan menyesuaikan diri dengan lingkungan yang baru maka akan berdampak susah memiliki teman (Hall, et al., 2016). Hal serupa disampaikan pula oleh Wardani dan Apollo (2010) bahwa salah satu permasalahan yang dihadapi oleh remaja adalah proses penyesuaian sosial. 
Hubungan yang terjalin antara remaja dengan lingkungan sebayanya memainkan peran yang penting bagi perkembangan keterampilan sosial, berkembangnya berbagai potensi kehidupan, serta berbagai fungsi di masa remaja (La Greca \& Lopez, 1998; Hansen, Nangle, \& Mayer, 1998). Menurut Kelly dan Hansen (dalam Hapsari \& Hasanat, 2010) terbinanya hubungan yang baik dengan teman sebaya membuat remaja dapat memperoleh fungsi positif, diantaranya adalah meningkatkan keterampilan sosial mengembangkan kemampuan penalaran, dan belajar untuk mengekspresikan perasaan dengan cara yang lebih matang.

Memiliki keterampilan sosial yang baik dapat membantu individu dalam proses penyesuaian sosial (Cartledge \& Milburn, 1995). Individu yang mampu menampilkan keterampilan sosial yang sesuai dengan tempat dimana mereka tinggal akan menjadikan individu tersebut lebih mudah melakukan penyesuaian. Perkembangan keterampilan sosial pada individu berkontribusi pada kestabilan emosi dimana mereka akan merasa diterima dan dihargai sehingga hal tersebut akan meningkatkan harga diri (Mota \& Motas, 2012).

Remaja yang kesepian dilaporkan memiliki keterampilan sosial yang buruk (Lodder, Goossens, Scholte, Engels, \& Verhagen, 2016). Individu dengan keterampilan sosial yang rendah mengalami kesulitan berinteraksi dengan orang lain. Hal tersebut membatasi mereka untuk membentuk dan mempertahankan persahabatan yang memuaskan dengan rekan-rekan mereka, sehingga mereka membatasi kuantitas hubungan sosial. Menurut Loder, et al. (2016) remaja akan lebih merasa kesepian jika dia mengevaluasi diri lebih buruk dari evaluasi yang dilakukan oleh teman- temannya atau mereka mengevaluasi diri positif namun teman-teman mengevaluasi diri mereka negatif. Spence (2003) menyatakan bahwa individu yang memiliki keterampilan sosial yang buruk serta hubungan yang sulit dengan teman, orang tua, serta guru diasosiasikan dengan banyak bentuk psikopatologi seperti depresi, conduct disorder, social phobia, autis, serta sindrom asperger.

Proses penyesuaian sosial akan menjadi baik jika individu memiliki keterampilan sosial yang baik pada saat berada di lingkungan yang baru. Menurut Cartledge dan Milburn (1995) keterampilan sosial merupakan kemampuan bersosialisasi dengan orang lain dalam konteks sosial dengan cara tertentu sehingga individu akan diterima atau dihargai secara sosial dan akan saling menguntungkan satu sama lain. Trower (dalam Cartledge \& Milburn, 1995) selanjutnya membagi keterampilan sosial ke dalam dimensi perilaku dan dimensi kognitif menjadi skill component (cara memandang atau rangkaian perilaku dalam berinteraksi) dan skill processes (tampilan perilaku sesuai dengan aturan dan tujuan sosial).

Menurut Cartledge dan Wilburn (1995) terdapat faktor-faktor yang memengaruhi keterampilan sosial individu, yaitu: 1) karakteristik individu dan 2) kriteria sosial dalam pemilihan keterampilan. Karakteristik individu berkaitan dengan tahap perkembangan individu, gender, serta kemampuan kognitif dan perilaku yang kurang berkembang dengan baik, sedangkan, kriteria sosial dalam pemilihan keterampilan merujuk pada konteks budaya dalam mempelajari keterampilan sosial, situasi spesifik, hubungan dengan teman, serta validitas sosial yaitu individu dapat menunjukkan perilaku yang sesuai 
dengan harapan atau tuntutan masyarakat.

Riggio (1986) menyatakan bahwa keterampilan sosial sebagai kemampuan dasar dalam menyampaikan serta menerima informasi dari orang lain yang direpresentasikan ke dalam dua dimensi yaitu: emotional (non verbal) dan social (verbal). Selanjutnya kedua dimensi ini akan dievaluasi berdasarkan tiga aspek, yaitu: 1) expressitivity, 2) sensitivity, serta 3) control. Proses ini melibatkan kemampuan kognitif seperti kemampuan interpersonal problem-solving dan kemampuan role playing. Berdasarkan dimensi dan juga aspek keterampilan sosial oleh Riggio (1986), kemudian terdapat enam domain keterampilan sosial, yaitu 1) emotional expressivity, 2) emotional sensitivity, 3) emotional control, 4) social expressitivity, 5) social sensitivity, dan 6) social control.

Collins dan Collins

menyatakan bahwa pelatihan keterampilan sosial merupakan peningkatan kualitas interaksi antar individu dalam lingkup pekerjaan yang dilakukan secara sosial. Individu akan berusaha keras untuk dapat bertemu serta berfungsi secara keseluruhan dalam hubungan sosial yang dilakukannya. Pelatihan keterampilan sosial tidak hanya melibatkan perilaku tetapi juga memerlukan proses kognitif mengenai diri mereka sendiri yang kemudian akan ditunjukkan oleh individu dalam bentuk perilaku. Sejalan dengan hal tersebut, menurut Koehler (2012) pelatihan keterampilan sosial efektif diberikan untuk remaja dengan memfokuskan pada proses pengajaran kemampuan untuk mencapai sukses dalam situasi sosial tertentu serta untuk mengenali stimulus yang tepat. Menurut Spence (2003) pelatihan keterampilan sosial bertujuan untuk meningkatkan kemampuan dengan menujukkan perilaku sosial sehingga individu sukses saat berada dalam situasi sosial. Menurut Goforth, Rennie, Hammond, \& Closson (2016) intervensi kelompok yang berfokus pada keterampilan sosial sangat berguna karena hal ini memungkinkan praktisi untuk mengajar satu set keterampilan untuk beberapa individu dan memfasilitasi pengembangan keterampilan sosial dalam setiap sesi. Kelly (dalam Hapsari dan Hasanat, 2010) menyatakan bahwa pelatihan keterampilan sosial dapat dilakukan secara berkelompok dengan jumlah empat sampai delapan orang jika pelatihan dilaksanakan dalam beberapa jam setiap pertemuannya. Terdapat beberapa manfaat pelatihan keterampilan sosial antara lain menurunkan kecemasan (Hapsari dan Hasanat, 2010; Miers, Blote, \& Westenberg, 2009), menurunkan agresi verbal pada remaja (Babakhani, 2011), membantu remaja yang mengalami kesulitan bergaul (Ramdhani \& Martaniah, 1995), meningkatkan konsep diri, efikasi diri, serta penyesuaian perilaku sosial (Harrel, Mercer \& DeRosier, 2008), dan menurunkan depresi pada remaja terutama remaja laki-laki (Reed, 1994).

Pendekatan yang digunakan dalam proses pelatihan adalah experiential learning. Menurut Kolb (1984) proses pada experiential learning terdapat sebuah siklus pembelajaran dengan empat tahapan. Tahap pertama adalah concrete experience, pada tahap ini belajar dari pengalaman yang ditemuinya. Selanjutnya adalah tahap abstract conceptualization individu melakukan analisis terhadap ide-ide yang ada. Tahap ketiga adalah reflective observation, pada tahap ini individu melakukan observasi secara berhati-hati sebelum membuat suatu keputusan Tahapan terakhir adalah active experimentation merupakan tahap dimana individu menunjukkan perilaku yang telah dipelajari. 
Pengembangan modul dalam penelitian ini menggunakan model Russel. Russel (dalam Ahmad, Hasan, dan Abidin, 2008; Ahmad, Sulaiman, Abdullah, Shamsudin, 2009; Ahmad, Amat, Yahaya, Yusof, \& Alias, 2011; Zuki dan Hamzah, 2014) mengembangkan tahapan dalam proses pembuatan modul. Tahapan tersebut yaitu: (1) menentukan subjek yang akan mendapat pelatihan dari modul yang dikerjakan, (2) mengidentifikasi tujuan dalam proses pembuatan modul, (3) mengembangkan alat ukur berdasarkan tujuan dari proses pembuatan modul untuk mengetahui level pencapaian dari para peserta, (4) melakukan analisis, (5) menyusun bagian modul, melakukan uji coba awal, dan (7) melakukan uji reliabilitas dan validitas. Setelah rangkaian tersebut dilakukan maka modul siap untuk diimplementasikan.

Menurut Russell (dalam Ahmad, et al., 2008; Ahmad et al., 2011; Zuki dan Hamzah, 2014) sebuah modul dapat dikatakan memiliki validitas isi yang baik apabila modul tersebut mencapai populasi yang ditargetkan, situasi pada saat proses pelaksanaan modul bagus dan memuaskan, waktu yang dialokasikan untuk subjek menjalankan modul cukup, terdapat peningkatan performa subjek setelah menjalankan modul, serta terdapat perubahan sikap menjadi lebih baik setelah menjalankan kegiatan pada modul.

Modul "CAKAP" dibutuhkan oleh mahasiswa baru asal Bali yang tergabung dalam KMHD UGM dikarenakan para mahasiswa baru datang ke daerah dengan kondisi lingkungan yang berbeda dari daerah asal serta bertemu dengan individu yang berasal dari latar belakang budaya yang berbeda. Agar dapat menyesuaikan diri dengan lingkungan sosial yang baru maka diperlukan pelatihan untuk meningkatkan pengetahuan serta keterampilan pada mahasiswa baru asal Bali dalam melakukan keterampilan sosial pada lingkungan yang baru.

Tujuan dari penelitian ini adalah melakukan validasi modul "CAKAP" (Cara untuk Asertif, Komunikatif, dan emPati) untuk meningkatkan keterampilan sosial remaja asal Bali pada lingkungan yang baru. Hipotesis yang diajukan pada penelitian ini adalah modul "CAKAP" (Cara untuk Asertif, Komunikatif, dan empati) valid untuk meningkatkan keterampilan sosial remaja Bali pada situasi lingkungan yang baru. Hasil penelitian ini diharapkan dapat memberikan kontribusi terhadap bidang psikologi khususnya psikologi pendidikan dalam bentuk modul pelatihan pada remaja. Implikasi dari penelitian ini secara praktis adalah dapat membantu remaja asal Bali yang tergabung dalam KMHD untuk menampilkan keterampilan sosial yang tepat saat berada di lingkungan yang baru selain itu nantinya modul dapat digunakan untuk membantu mahasiswa asal Bali.

\section{Metode}

Penelitian ini melibatkan 14 orang peserta yang kemudian dibagi ke dalam dua kelompok, yaitu kelompok eksperimen dan kelompok kontrol. Subjek penelitian dipilih dengan teknik purposive sampling dengan kriteria a) mahasiswa asal Bali, b) berada di semester 1 hingga 2 atau mahasiswa yang sedang berada pada tahun pertama perkuliahan, c) memiliki nilai keterampilan sosial dalam kategori sedang, d) belum pernah mengikuti pelatihan keterampilan sosial sebelumnya, dan e) bersedia mengikuti seluruh sesi pelatihan. Desain penelitian yang digunakan adalah untreated control group design with dependent pretest and posttest samples dengan membagi peserta menjadi 
2 kelompok, yaitu kelompok eksperimen dan kelompok kontrol (Shadish, Cook dan Campbell, 2002).

Skala keterampilan sosial yang digunakan dalam penelitian ini dibuat berdasarkan teori keterampilan sosial milik Riggio. Skala diberikan kepada seluruh subjek penelitian sebagai pre-test dan post-test. Uji validitas skala keterampilan sosial melibatkan 20 orang lulusan magister profesi psikologi, yang kemudian dianalisis menggunakan uji Aiken's $V$. Validitas isi skala keterampilan sosial berkisar antara 0,675-0,875. Hal ini berarti aitem pada skala keterampilan sosial yang disusun memiliki validitas isi yang baik. Uji coba skala dilakukan terhadap 100 orang yang kemudian dianalisis menggunakan Alpha Cronbach dan diperoleh koefisien reliabilitas sebesar 0,862 . Dari aitem yang bertahan, dipilih 24 aitem yang digunakan. Selain itu, dalam proses pelatihan digunakan lembar observasi untuk mencatat proses pelatihan yang telah berlangsung serta keterlibatan peserta dalam pelatihan. Pada akhir sesi pelatihan, peserta diberikan lembar evaluasi untuk menilai hal-hal yang berkaitan dengan proses pelatihan.

Modul pelatihan "CAKAP" adalah modul pelatihan keterampilan sosial yang diberikan kepada mahasiswa baru asal Bali. Proses penyusunan modul didahului dengan studi pendahuluan untuk mengetahui kebutuhan subjek. Selanjutnya, disesuaikan dengan teori mengenai keterampilan sosial. Modul disusun dengan menggunakan teori keterampilan sosial milik Riggio (2005) serta teori mengenai hambatan dalam menampilkan keterampilan sosial milik Spence (2003).
Proses penyusunan modul didampingi oleh dosen pembimbing.

Proses validasi modul meliputi dua bagian, yaitu uji validitas isi serta uji empirik. Uji validitas isi menggunakan penilaian dari ahli yang kemudian dianalisis statistik dengan Aiken's $V$. Selanjutnya, uji empirik dilakukan dengan memberikan pelatihan berdasarkan modul yang disusun dengan kriteria subjek yang sesuai dengan modul. Data yang diperoleh setelah uji empirik, dianalisis menggunakan uji statistik Mann-Whitney $U$ merupakan uji statistik yang digunakan untuk mengetahui perbedaan pada dua kelompok (Field, 2005). Selain itu, analisis uji beda antara pre-test dan post-test baik pada kelompok eksperimen maupun kelompok kontrol menggunakan uji Wilcoxon (Field, 2005).

\section{Hasil}

\section{Uji validitas isi modul}

Uji validitas isi modul dilakukan dengan meminta masukan dari para ahli (Arip, Bakar, Ahmad, dan Jais, 2013). Penilaian dilakukan dengan melibatkan sembilan orang ahli. Ahli tersebut merupakan dosen psikologi serta psikolog yang memahami dunia remaja dan pelatihan. Hasil penilaian tersebut kemudian diolah menggunakan analisis Aiken's $V$ dengan hasil seperti yang disajikan pada Tabel 1 .

Menurut Azwar (2015) rentang angka $\mathrm{V}$ berkisar antara 0 sampai dengan 1. Hasil penilaian setiap sesi pada modul berkisar antara 0,734-0,861. Hal ini berarti koefisien Aiken's yang diperoleh cukup tinggi pada setiap sesi. 
Tabel 1.

\begin{tabular}{cc} 
Nilai Aiken's $V$ modul “CAKAP" \\
\hline $\begin{array}{c}\text { Sesi } \\
\text { Pelatihan }\end{array}$ & Aiken's $V$ \\
\hline Sesi 1 & 0,854 \\
Sesi 2 & 0,778 \\
Sesi 3 & 0,764 \\
Sesi 4 & 0,772 \\
Sesi 5 & 0,734 \\
Sesi 6 & 0,756 \\
Sesi 7 & 0,861 \\
\hline
\end{tabular}

Penilaian secara kualitatif juga dilakukan pada modul yang digunakan. Terdapat masukan yang diberikan kepada modul pelatihan, yaitu memberikan contoh pada sesi-sesi tertentu sehingga materi yang diberikan dapat dengan mudah dipahami oleh para peserta, memberikan gambaran yang spesifik terhadap permainan-permainan yang digunakan, dan pengurangan waktu pada beberapa sesi sehingga pelatihan berjalan lebih efektif.

\section{Uji empirik}

Sebelum pelatihan dimulai, semua subjek di kelompok eksperimen dan kelompok kontrol diberikan pre-test berupa skala keterampilan sosialhseorang trainer dengan kualifikasi: lulusan magister psikologi profesi atau berpengalaman dalam memberikan pelatihan pada remaja, memahami dan menyukai dunia remaja, serta dapat bersikap interaktif pada proses pelatihan berlangsung.

Pemberian post-test untuk skala keterampilan sosial dilakukan tiga hari setelah pelatihan berlangsung yaitu pada tanggal 17 Mei 2017 pada kelompok eksperimen dan tanggal 18 Mei 2017 pada kelompok kontrol.

Nilai keterampilan sosial yang diperoleh kelompok eksperimen sebelum dan setelah proses pelatihan dapat dilihat pada tabel 2. Berdasarkan tabel tersebut, diketahui bahwa rata-rata skor skala keterampilan sosial sebelum diberikan pelatihan yaitu 71,29 dan skor skala keterampilan sosial sesudah pemberian pelatihan yaitu 82,29 .

Nilai keterampilan sosial yang diperoleh kelompok kontrol sebelum dan setelah proses pelatihan dapat dilihat pada Tabel 3. Berdasarkan Tabel 3, diketahui bahwa rata-rata skor skala keterampilan sosial sebelum diberikan pelatihan yaitu 78,71 dan skor skala keterampilan sosial sesudah pemberian pelatihan yaitu 80,42 .

Tabel 2.

Hasil skala keterampilan sosial pada kelompok eksperimen

\begin{tabular}{ccccc}
\hline \multirow{3}{*}{ Kelompok } & \multirow{2}{*}{ Subjek } & \multicolumn{2}{c}{ Raw Score } & Gain score \\
\cline { 3 - 5 } & APre- & Post- & \\
& test & test & 8 \\
MR & 77 & 85 & 21 \\
Eksperimen & 68 & 89 & 3 \\
& FA & 77 & 80 & 23 \\
& KA & 61 & 84 & 5 \\
Rerata & BM & 74 & 85 & 7 \\
& CS & 68 & 75 & 4 \\
& RM & 74 & 78 & 10,14 \\
\hline
\end{tabular}


Tabel 3.

Hasil skala keterampilan sosial pada kelompok kontrol

\begin{tabular}{|c|c|c|c|c|}
\hline \multirow{2}{*}{ Kelompok } & \multirow{2}{*}{ Subjek } & \multicolumn{2}{|c|}{ Raw Score } & \multirow[t]{2}{*}{ Gain score } \\
\hline & & Pre-test & Post-test & \\
\hline \multirow[t]{7}{*}{ Kontrol } & $\mathrm{PH}$ & 77 & 77 & 0 \\
\hline & DY & 74 & 82 & 8 \\
\hline & BA & 86 & 89 & 3 \\
\hline & MW & 83 & 76 & -7 \\
\hline & $\mathrm{TH}$ & 69 & 77 & 8 \\
\hline & $\mathrm{MH}$ & 84 & 84 & 0 \\
\hline & PT & 78 & 78 & 0 \\
\hline Rerata & & 78,71 & 80,42 & 1,71 \\
\hline
\end{tabular}

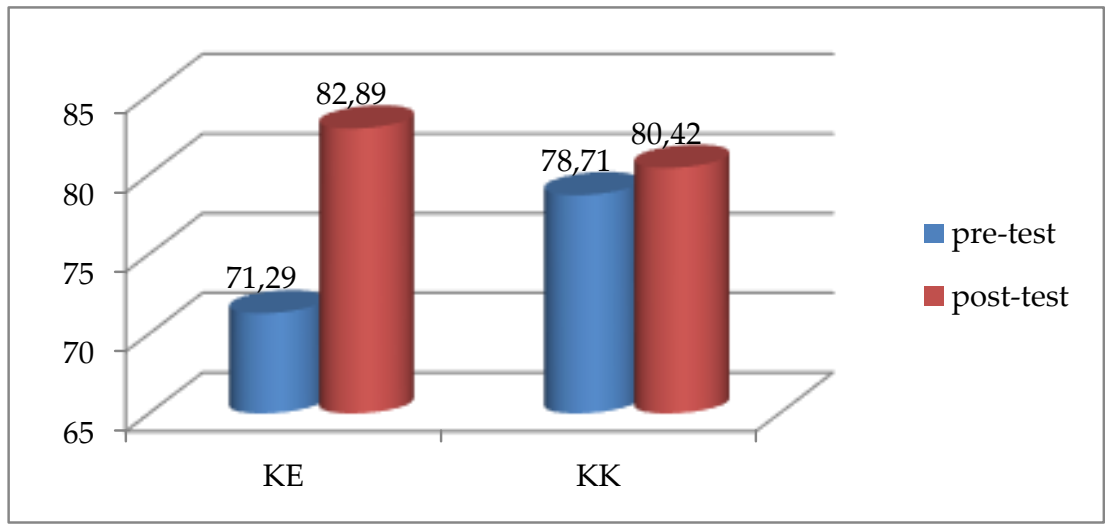

Gambar 1. Grafik Perbedaan Sebelum dan Setelah Pelatihan pada Kelompok Eksperimen dan Kelompok Kontrol

Gambar 1. merupakan grafik perubahan skor skala keterampilan sosial pada peserta pelatihan sebelum dan sesudah pelaksanaan pelatihan Modul "CAKAP". Gambar 1. menunjukkan bahwa terjadi peningkatan skor keterampilan sosial pada mahasiswa baru asal Bali baik pada kelompok eksperimen maupun kelompok kontrol. Kelompok eksperimen mengalami peningkatan skor skala keterampilan sosial sebesar 10,14, sedangkan kelompok kontrol sebanyak 1,71 .

Uji empirik peneliti menggunakan uji statistik Mann-Whitney $U$ test. Uji ini dilakukan dengan membandingkan gain score data pre-test dan post-test pada kelompok eksperimen dan kelompok kontrol. Berdasarkan hasil analisa data menunjukkan nilai $z=-2,194$ dan $p=0,026$ $(p<0,05)$. Hal ini menunjukkan bahwa terdapat perbedaan yang signifikan antara skor keterampilan sosial kelompok eksperimen dengan kelompok kontrol.

Terlihat dari rata-rata nilai gained score kelompok eksperimen sebesar 10,14 dan nilai gained score kelompok kontrol sebesar 1,71. Maka disimpulkan bahwa Modul "CAKAP" dapat meningkatkan keterampilan sosial pada mahasiswa baru asal Bali.

\section{Diskusi}

Modul merupakan sebuah paket instruksi yang disesuaikan dengan kebutuhan peserta dalam menguasai suatu materi (Russel \& Johaningsmier, 1981). Oleh 
karena itu, sebelum dapat digunakan maka diperlukan uji validitas pada modul tersebut. Proses validasi modul dibagi ke dalam dua tahapan, yaitu uji validitas isi dan uji empirik (Ayriza, 2008).

Berdasarkan hasil uji validitas isi modul, yang telah dilakukan pada modul "CAKAP" memiliki validitas isi yang baik dengan nilai Aiken's V pada setiap sesinya Berkisar dari 0,734-0,861. Penilaian terhadap modul dilakukan oleh para ahli terhadap redaksional bahasa, prosedur pelaksanaan, permainan yang digunakan, serta lembar kerja dalam modul . Penilaian modul juga dilakukan secara kualitatif dengan catatan yang diberikan terkait dengan prosedur pelaksanaan, alokasi waktu pada saat proses pelatihan, serta pemberian contoh pada materi yang diberikan (Agustini, 2017). Russel dan Johanningsmier (1981) menyatakan bahwa dalam proses penerapan modul terdapat hal-hal yang harus diperhatikan yaitu, peran trainer, pengaturan pada modul, fasilitas, peralatan, serta proses dalam penilaian. Peran trainer dalam proses pelatihan antara lain mengajak para peserta untuk terlibat dalam proses pembelajaran, membuat materi yang disampaikan menjadi menarik, menyusun instruksi yang akan disampaikan, serta mampu memahami kondisi dari peserta. Hasil evaluasi terhadap trainer dari observer, trainer dapat menyampaikan materi dengan baik disertai dengan contoh-contoh yang mudah dipahami oleh peserta namun untuk materi tertentu trainer masih tampak agak gugup.

Selanjutnya, pengaturan dalam modul menurut Russel dan Johanningsmier (1981) diartikan sebagai pengaturan waktu yang dibutuhkan dalam melakukan kegiatan yang ada pada modul. Berdasarkan hasil evaluasi yang dilakukan waktu dalam proses pelatihan sudah cukup namun ketepatan waktu dalam proses pelatihan masih kurang hal ini disebabkan oleh keterlambatan datangnya peserta pelatihan. Fasilitas dan peralatan yang digunakan dalam proses pelatihan sudah dapat dengan baik mendukung dengan baik jalannya proses pelatihan. Ruangan yang digunakan dalam proses pelatihan cukup untuk peserta melakukan semua aktivitas yang ada pada modul. Peralatan yang digunakan seperti LCD, pengeras suara, serta kursi mendukung proses penyampaian materi. Hasil evaluasi dari peserta mengenai peralatan yang digunakan mendapat penilaian yang cukup.

Proses penilaian dalam pelatihan ini dapat dilihat dari nilai pretest dan posttest yang diperoleh serta hasil dari evaluasi yang diberikan oleh observer (Russel \& Johanningsmier, 1981). Berdasarkan hasil penilaian pretest dan posttest yang diperoleh terjadi peningkatan nilai pada peserta yang mengikuti pelatihan. Jika dibandingkan dengan kelompok kontrol, nilai yang dimiliki kelompok eksperimen lebih tinggi. Berdasarkan penilaian dari observer, peserta dapat mengikuti setiap kegiatan yang diberikan. Beberapa peserta di awal proses pelatihan sempat malumalu dalam menyampaikan pendapat, namun dengan bantuan dari trainer dan $\mathrm{co}^{-}$ trainer para peserta dapat aktif baik bertanya maupun menjawab serta melakukan simulasi saat pelatihan berlangsung.

Hasil uji empiris yang dilakukan menunjukkan terjadi peningkatkan keterampilan sosial pada mahasiswa baru asal Bali setelah mendapatkan pelatihan dengan modul "CAKAP". Skor keterampilan sosial pada kelompok eksperimen lebih tinggi dibandingkan dengan skor keterampilan sosial pada kelompok kontrol. Oleh karena itu, dapat disimpulkan bahwa modul pelatihan 
"CAKAP" memenuhi kriteria modul yang memiliki validitas yang baik.

Berdasarkan hasil uji empiris, diketahui pula pada kelompok eksperimen tidak terjadi perbedaan kategorisasi skor sebelum dan setelah perlakuan. Namun, terjadi perubahan yang signifikan. Sedangkan pada kelompok kontrol tidak terjadi perubahan yang signifikan dan kategorisasi skor juga tetap berada di kategorisasi sedang.

Data menunjukkan bahwa skor pretest pada kelompok kontrol lebih tinggi dibandingkan dengan skor pretest pada kelompok eksperimen. Peristiwa ini dapat disebabkan oleh beberapa hal, salah satunya adalah validitas internal yaitu seleksi subjek. Menurut Cook \& Campbell (1979) seleksi merupakan salah satu yang dapat mengancam validitas internal dalam penelitian eksperimen kuasi. Seleksi sering menjadi ancaman dikarenakan kelompok akan mendapatkan perlakukan yang berbeda, namun kondisi kelompok bukanlah kelompok yang setara.

Selain itu, hal yang terjadi pada kedua kelompok dapat dijelaskan dengan teori ceiling effect. Koedel dan Betts (2009) menjelaskan ceiling effect merupakan kecenderungan kenaikan nilai tes pada subjek menjadi lebih kecil jika skor awal mengarah pada ujung distribusi. Hal ini terjadi pada kelompok kontrol, terdapat perbedaan yang tidak terlalu jauh yang bisa saja disebabkan karena nilai pretest pada kelompok kontrol memang sudah tinggi. Nilai tertinggi yang diperoleh dari kedua keompok pada pretest dan posttest yaitu 89. Ceiling effect sendiri dapat terjadi dalam suatu penelitian salah satunya dikarenakan oleh tidak dilakukannya matching atau penyetaraan setelah melakukan pretest pada kedua kelompok penelitian (Blair \& Imai, 2012).

Keterbatasan dalam penelitian ini berdasarkan hasil evaluasi yang dilakukan kepada peserta pelatihan diperoleh bahwa diperlukan tambahan untuk simulasi sehingga peserta dapat lebih memahami materi dengan lebih baik. Peneliti tidak melakukan penyetaraan nilai pada kelompok eksperimen dan kelompok kontrol setelah pemberian pre-test, hal ini menyebabkan terjadinya ceiling effect pada proses penelitian. Selain itu, dalam penelitian ini peneliti tidak melakukan pengukuran secara berkelanjutan (followup) disebabkan oleh waktu yang tidak mencukupi.

\section{Kesimpulan}

Berdasarkan hasil penelitian, dapat disimpulkan bahwa modul pelatihan "CAKAP" terbukti valid untuk meningkatkan keterampilan sosial pada mahasiswa baru asal Bali.

\section{Saran}

Berdasarkan hasil diskusi penelitian, maka peneliti memberikan rekomendasi untuk peneliti selanjutnya. Pertama, melakukan matching pada kelompok eksperimen dan kelompok kontrol sehingga kedua kelompok yang digunakan dalam penelitian setara. Kedua, menggunakan modul pelatihan "CAKAP" tidak hanya pada mahasiswa baru, tetapi juga pada mahasiswa semester atas yang mengalami permasalahan berkaitan dengan keterampilan sosial. Ketiga, melakukan follow-up pada penelitian selanjutnya untuk mengetahui efek jangka panjang dari proses pelatihan dengan modul "CAKAP" karena pada penelitian ini tidak dilakukan follow-up. Keempat, penelitian selanjutnya menggunakan subjek yang memiliki kategorisasi nilai keterampilan sosial pada kategori rendah. 


\section{Kepustakaan}

Abeele, M., \& Roe, K. (2011). A new life, old friends: A cross-cultural comparison of the use of communication technologies in the social life of college freshmen. Young, 19(2), 219-240. doi: $\underline{10.117 /}$ $\underline{110330881001900205}$

Agustini, N. M. (2017). Validasi modul petik cakap untuk meningkatkan keterampilan sosial mahasiswa baru asal Bali. (Skripsi Tidak Dipublikasikan). Yogyakarta: Fakultas Psikologi Universitas Gadjah Mada.

Ahmad, J., Amat, M., Yahaya, S., Yusof, R., \& Alias, S. (2011). The construction, validity, reliability, and effectiveness of drug rehabilitation module on self-concept of female addicts and motivation achievement of male addicts in Malaysia. International Journal of Humanities and Social Science, 1(1), 217-228

Ahmad, J., Hassan, A., \& Abiddin, N. (2008). Developing, validity, and reliability of a drug addiction module among drug addicts who are undergoing treatment at rehabilitation centre. The Journal of International Social Research, 1(5), 4757.

Ahmad, J., Sulaiman, T., Abdullah, S. K., \& Shamsuddin, J. (2009). Building a customized module for treatment of drug addiction uncler the remedial programs to be implemented on inmates at te drug rehabilitation center in Malaysia. US-China Education Review, 6(11), 57-64

Arip, M., Bakar, R., Ahmad, A. \& Jais, S. (2013). The development of a group guidance module for student selfdevelopment based on gestalt theory. Journal Social and Behavioral Science, 84, 1310-1316.
Ayriza, Y. (2008). Penyusunan dan validasi modul "Social life skill" bagi pendidik anak pra-sekolah. Jurnal Penelitian dan Evaluasi Pendidikan, (2), 213-231

Azwar, S. (2015). Reliabilitas dan validitas: Edisi 4. Yogyakarta: Pustaka Pelajar.

Babakhani, N. (2011). The effects of social skills training on self-esteem and aggresion male adolescents. Social and behvioral Science, 30, 1565-1570. Tersedia di www.sciencedirect.com

Blair, G. \& Imai, K. (2012). Statistical analysis of list experiments. Political Analysis, 20, 47-77. doi: 10.1093/ $\mathrm{pan} / \mathrm{mpr} 048$

Cartledge, G., \& Milburn, J. (1995). Teaching social skill to children and youth. Massachusetts: Allyn and Bacon.

Collins, J., \& Collins, M. (1992). Social skills training and the profesional helper. England: John Willey \& Sons.

Cook, Thomas D \& Campbell, Donald T. (1979). Quasi experimentation design $\mathcal{E}$ analysis issues for field settings. Boston: Houghton Mifflin Company

Field, A. (2005). Discovering statistics using SPSS second edition. London: Sage Publications.

Goforth, A., Rennie, B., Hammond, J., \& Closson, J. (2016). Strategies for data collection in social skills group intervention: A case study. Intervention in School and Clinic, 51 (3), 170-177. doi: $\underline{10.117 / \text { I0534 } 51215}$ $\underline{585806}$

Hall, E., McNallie, J., Custers, K., Timmermans, E., Wilson, S., \& Bulk, J. (2016). A cross-cultural examination of the mediating role of family support and parental advice quality on the relationship between family communication patterns and first-year college student adjustment in the United States and Belgium. 
Communication Research, 1-30. doi: 10. $\underline{1177 / 0093650216657755}$

Hansen, D., Nangle, D., \& Meyer, K. (1998). Enhancing the effectiveness of social skills intervention with adolescents. Educational and Treatment of Children, 21(4), 489-513.

Hapsari, M., \& Hasanat, N. (2010). Efektivitas pelatihan keterampilan sosial pada remaja dengan kecemasan sosial. Psycho Idea, 8(1), 18-37.

Harrel, A., Mercer, S., \& DeRosier, M. (2008). Improving the socialbehavioral adjustment of adolescents: The effectiveness of a social skills group intervention. Journal Children Family Study, 18, 378387. doi: 10.1007/s10826-008-9241-y

Koedel, C. \& Betts, J. 2009. Value added to what? How a ceiling in the testing instrument infulences value-added estimation. American Finance Association, 54-81.

Koehler, S. (2012). Social skill training for adolescent youth: Measurement of skill acquisition (Thesis). University of South Florida. United States. http://www.proquest.com

Kolb, D. A. (1984). Experiential learning: Experience as the source of learning and development. Englewood Cliff: Prentice Hall.

La Greca, A., \& Lopez, N. (1998). Social anxiety among adolescents: Linkage with peer relation and friendship. Journal of Abnormal Child Psychology, 26, 83-94.

Liu, R., \& Chang, K. (2014). The causal model of the freshmen year characteristics, campus experience, and learning outcomes for college student. Social and Behavioral Science, 116, 1383-1388. Tersedia di www.sciencedirect.com
Lodder, G., Goossens, L., Scholte, R., Engels, R., \& Verhagen, M. (2016). Adolescent loneliness and social skills: Agreement and discrepancies between self-, meta-, and peer evaluations. Youth Adolescence, 1-11, doi: 10.1007/s10964-016-1461-y

Miers, A., Blote, A., \& Westenberg, P. (2009). Peer perception of social skills in socially anxious and nonanxious adolescent. Journal Children Family Study, 38, 33-41. doi: 10.1007/s10802-009-9345-x

Mota, C., \& Motas, P. (2012). Peer attachment, coping, and self-esteem in institutionalized adolescents: The mediating role of social skills. Psychological Education, 28, 87-100. doi: $10.1007 / \mathrm{s} 10212-012-0103-\mathrm{z}$

Ramdhani, N., \& Martaniah, S. (1995). Pelatihan keterampilan sosial pada mahasiswa yang sulit bergaul. BPPSUGM, 8(2A), 149-157.

Reed, M. (1994). Social skills training to reduce depression in adolescents. Adolescence, 29(114), 293-302

Riggio, R. (2005). The social skills inventory (SSI): Measuring nonverbal and social skills. Dalam V. Manusov (Ed) The Sourcebook of Nonverbal Measures: Doing Beyond Words. Mahwah, NJ: Lawrence Erlbaum.

Riggio, R. (1986). Assesment of basic social skills. Journal of Personality and Social Psychology, 51(3), 649-660.

Russel, J., \& Johanningsmeier, K. (1981). Improving competence through modular instruction. USA: Kendall/Hunt.

Santrock, J. (2003). Adolescence, edisi keenam. Jakarta: Erlangga.

Shadish, Cook, \& Campbell. (2002). Experimental and quasi-experimental designs for generalized casual inference. Boston: Houghton Mifflin Company. 
Siregar, D. (2012). Pelatihan keterampilan sosial untuk mahasiswa Universitas Indonesia dengan distres psikologis tinggi (Tesis tidak dipublikasikan). Universitas Indonesia. Jakarta. Tersedia dari lib.ui.ac.id.

Spence, S. (2003). Social skills training with children and young people: Theory, evidence, and practice. Child and Adolescent Mental Health, 8(2), 84-96.
Wardani, R., \& Apollo. (2010). Hubungan antara kompetensi sosial dengan penyesuaian sosial pada remaja. Widya Warta, 1, 92-104. 